\title{
Narrativas ao Sul: viagem e música em quatro romances de Assis Brasil
}

\author{
André Tessaro Pelinser ${ }^{1}$ \\ Maria Zilda Ferreira Cury²
}

Visitantes ao Sul é o título do conjunto de romances publicados por Luiz Antonio de Assis Brasil no início dos anos 2000, por meio do qual o autor retoma o clássico tema da viagem na literatura. A partir dessa proposição, abre-se campo fértil para a exploração da subjetividade humana, uma vez que o trânsito implica contato com espaços marcados por diferentes geografias e padrões culturais. A travessia, tão cara a Guimarães Rosa e a boa parte dos representantes do regionalismo no Brasil, é aqui reencenada, mas assumindo uma das vertentes mais sofisticadas da ficção contemporânea. Revisitando gêneros literários como os que conferiram particularidade às representações dos espaços regionais e de momentos importantes para a historiografia, a obra do escritor gaúcho relativiza a feição totalizadora dos diferentes discursos que coloca em diálogo nos seus textos.

Assis Brasil é um homem sensível e sabe que a História é repleta de falácias. A ficção torna-se, para ele, instrumento de desmistificação. Se a grandeza heroica sustentara, até então, grande parte das obras regionalistas, dedicadas a narrar a epopeia das guerras, fixando hábitos de vida, usos e costumes da campanha, ${ }^{3}$ o que o escritor agora propõe é a denúncia da intolerância (Masina, 1995, p. 17).

\footnotetext{
${ }^{1}$ Doutorando em estudos literários na Universidade Federal de Minas Gerais (UFMG), Belo Horizonte, MG, Brasil. Bolsista do CNPq. E-mail: andre.pelinser@gmail.com

${ }^{2}$ Doutora em literatura brasileira e professora da Universidade Federal de Minas Gerais (UFMG), Belo Horizonte, MG, Brasil. Pesquisadora do CNPq. E-mail: mariazildacury@ gmail.com

${ }^{3} \mathrm{O}$ ensaio de Léa Masina privilegia a análise do romance de Assis Brasil Videiras de cristal, narrativa em que é retomado o episódio histórico da Revolta Messiânica dos Muckers, ocorrida no Rio Grande do Sul em finais do século XIX. No entanto, as observações da pesquisadora são pertinentes para outros romances do escritor, como os que aqui analisamos, especialmente $O$ pintor de retratos. A pesquisadora se refere à revolta que se tornou um ícone da literatura regionalista riograndense, a Revolução Farroupilha, que aconteceu no Rio Grande do Sul em finais do século XIX, evento ressignificado pela obra de Assis Brasil. "A Revolução Farroupilha, luta ferrenha entre duas oligarquias elevada a símbolo de heroicidade do povo gaúcho, ressurge então, em seus aspectos mais sombrios, acentuando com nitidez a oposição entre grupos sociais” (Masina, 1995, p. 17).
} 
Debruçando-se sobre momentos cruciais de nosso passado, a obra de Assis Brasil dialoga com variadas formas discursivas.

A própria História é sua matriz, fonte que possibilita ao escritor a inovação temática, emprestando-lhe o eixo cronológico, ordenador da sintaxe narrativa. Diversas leituras possíveis remetem, pois, à função propriamente formadora da literatura, ressaltando a figura do escritor, sua responsabilidade e o papel que lhe cabe numa sociedade em desenvolvimento (Masina, 1995, p. 16).

Como em outros romances do escritor gaúcho, também naqueles que compõem Visitantes ao Sul é privilegiada a figura do intelectual lato sensu e sua função social, como apontado pela estudiosa. Além disso, pela ficcionalização de momentos reconhecíveis na nossa historiografia, é conferida às narrativas uma feição autorreflexiva, configurando quase metaficções historiográficas que revitalizam o gênero no efetivo privilégio concedido aos embates internos dos protagonistas. Ressalte-se, então, que o diálogo com o discurso da história, na sua feição de retomada memorialística, é filtrado pela subjetividade dos personagens, que exibem suas paixões e contradições.

Os quatro romances da série - O pintor de retratos (2001), A margem imóvel do rio (2003), Música perdida (2006) e Figura na sombra (2012) vertem para um mesmo ponto: ainda que por diversos caminhos, as personagens encontram no Rio Grande do Sul, principalmente nos três primeiros romances, um momento decisivo para suas vidas. De fato, embora seja local sempre provisório, é a região Sul o espaço eleito para o permanente trânsito das personagens e onde se encenam com maior densidade as problematizações dos enredos. Por sua vez, também é relevante a dimensão temporal, já que o passado, para os quatro protagonistas, retorna para impor questões e construir significados, variações, no ritmo dos seus passos e das recuperações memorialísticas.

O pintor de retratos, cujo percurso se inicia na Itália natal, parte primeiramente para a França e em seguida para o Brasil, aportando, não sabe o leitor como, em Porto Alegre. Já na passagem por Paris sofrera o primeiro dos muitos impasses com que se defrontaria ao longo de sua trajetória:

Houve o dia em que ele saiu para a rua, a cabeça fervente. Pensava em trocar de professor. Caminhava ao longo da rue de Saint Antoine quando percebeu que alguém o observava. Voltouse. O olhar vinha de uma vitrina. Não era uma pessoa. Era uma 
pessoa numa fotografia. [...] Nessa noite ele caminhava como um celerado pelo quarto. Dormiu às duas da madrugada e teve um sonho lascivo (Assis Brasil, 2002, p. 25).

Tratava-se da foto da atriz Sarah Bernhardt feita pelo célebre Félix Nadar e estampada na vitrine de uma loja parisiense. A fulgurante aparição faz com que Sandro Lanari julgue-se impossibilitado de continuar pintando retratos. Como fazê-lo se a perfeição lograda pela recém-surgida técnica fotográfica lhe parecia inalcançável pela pintura? Como reproduzir com pincéis a beleza perturbadora da atriz famosa? Logo nos primeiros capítulos, então, já se coloca em xeque a questão da representação, isto é, a pretensão artística de reproduzir o real. Metáfora dos impasses de representação da própria narrativa literária, cujo percurso o leitor inicia, a impossibilidade de dizer a realidade é Leitmotiv presente nos outros livros da série.

Fascinado pelo trabalho de Nadar, o pintor, deambulando pelas ruas parisienses, se depara com a exposição de outras fotos, perturbando-se sempre com o que via, obrigado a refletir sobre os parâmetros de sua própria arte, impotente que era diante do esplendor da imagem fotográfica. À diferença do artista flâneur de Baudelaire, Sandro Lanari não volta para casa com a inspiração proporcionada pela vitalidade urbana, não trabalha "violento, ativo, como se temesse que as imagens lhe escapassem, belicoso, mas sozinho e debatendo-se consigo mesmo" (Baudelaire, 2002, p. 23-24). Pelo contrário, o que encontra nas ruas da cidade desestimula sua arte, embora promova o embate interior que fará deslanchar os diferentes trânsitos do personagem. "Retornando ao gabinetto, Sandro encarou dois retratos ainda em seus cavaletes. Soltou um $a h$ ! de impotência e repulsa, e gritou tão forte que o som saiu pela janela e foi ouvido no térreo pela concierge do prédio [...]" (Assis Brasil, 2002, p. 29, grifo no original). Com efeito, Nadar passa a representar para o pintor uma espécie de alter ego a acompanhá-lo como uma sombra. "Ainda que Sandro não soubesse, Nadar entrara para sempre em sua vida" (Assis Brasil, 2002, p. 29).

Sistematizando em várias publicações a feição que adquire o romance histórico na literatura brasileira contemporânea, Marilene Weinhardt, num dos seus ensaios, define o gênero como:

texto ficcional em que a historicidade é determinante para o enredo, ou seja, a obra em que a inscrição dos fatos narrados em um determinado tempo passado é decisiva para que eles tenham 
ocorrido como tal e, de modo explícito ou não, o texto dialoga com o discurso histórico [...]. E mais, tais acontecimentos não dizem respeito apenas àqueles seres ficcionalizados, as personagens desse romance, mas afetaram e afetam os coetâneos, quer dizer, os indivíduos que viveram e vivem a mesma época (Weinhardt, 2006, p. 137-138).

Em $O$ pintor de retratos, alcança-se, por meio do impacto que a fotografia teve na vida do protagonista, uma reflexão sobre o abalo que a técnica fotográfica causou às artes plásticas, notadamente à pintura.

As relações entre Impressionismo, o movimento artístico que marcou a pintura francesa do século XIX, e fotografia foram particularmente estreitas. Buscando expressar na superfície da tela impressões (nunca as mesmas) de realidades (a cada vez diferentes), os impressionistas, por um lado, repudiaram a arte mimética, o que não deixou de configurar uma resposta à recém-criada arte fotográfica. Por outro, os mesmos impressionistas fizeram a incorporação de técnicas fotográficas nos quadros. Situando, pois, a personagem e seu embate com a foto da grande atriz francesa e o impacto que esta última teve nos rumos que o pintor imprimiria à sua vida, assume a narrativa, como uma mise en abyme, uma reflexão sobre os impasses da arte na época.

O próprio narrador se incumbe de sutilmente ir "fotografando" cenas que constituem um panorama do espaço urbano da modernidade da capital francesa: a grande exposição universal, o burburinho das ruas, o acolhimento de Nadar aos impressionistas, o salão de exposições dos artistas modernos ("Salon des Refusés?"), com referências também sutis aos pintores/expositores (Monet? Renoir? Manet?) e alusões a quadros - por exemplo, o de Picasso: "Passou a sua frente um gato malhado e triste, carregando na boca um pardal morto" (Assis Brasil, 2002, p. 40). Todas essas cenas a ambientar a perplexidade de Sandro Lanari diante de uma arte que ele não compreende, mas que percebe como oposta à sua própria, uma arte que fugia completamente aos parâmetros que guiaram até então seu ofício de retratista, expressão de "uma verdade a que ele nunca atingiria" (Assis Brasil, 2002, p. 40).

Sandro postou-se à frente de um retrato de uma jovem mulher envolta em tecido vaporoso, talvez voile. Percebia-se a carne, por debaixo. Sim, havia qualquer senso de volume e de transparência, era inegável, mas onde terminava o braço, onde as mãos? Aquela 
gente apreciava quadros inacabados? E a moldura rica? Não se põe moldura num esboço (Assis Brasil, 2002, p. 39).

O estranhamento sentido por Lanari evidencia como os parâmetros de sua arte de retratista situavam-se na representação o mais próxima possível do modelo, na observação detalhista. Mas o século XIX opõe os retratos privados aos retratos oficiais e àqueles expostos bem visivelmente nas salas burguesas. Assim é a célebre Olympia, de Manet, retrato inspirado na tradição clássica, mas representando não a Vênus de Urbino, de Tiziano, ou a Vênus dormindo, de Giorgioni, e sim a figura de sua modelo Victorine Meurent, que desafia, arrogantemente, o espectador. Os retratos de Toulouse-Lautrec, para referir mais um exemplo, trazem à frente da tela as coristas, os personagens de teatro. A arte impressionista não pode ser compreendida sem levar em conta o impacto da espontaneidade e da invenção da fotografia que "flagra" atitudes do quotidiano dos retratados, muitos deles artistas, mas também anônimos, "tipos humanos" captados pelas lentes da máquina.

Promovendo também o diálogo com outras manifestações artísticas, como a escultura, afirma-se a fotografia como arte já nos primeiros tempos de seu aparecimento. Veja-se que é a partir de uma analogia à escultura que Sandro Lanari deixa-se atrair pelo retrato de Sarah Bernhardt: "Uma alegre prostituta de olhos transparentes de luz, envolta num pano à romana, alvo, com borlas e franjas. À mostra ficavam os ombros de uma carnação firme, curva e saudável. Os cabelos negros, separados ao meio, eram as asas esvoaçantes da Vitória de Samotrácia" (Assis Brasil, 2002, p. 25). Com efeito, o retrato de Nadar, significativamente estampado na capa do livro de Assis Brasil, sobretudo pelo trabalho de luz e sombra nas vestes da atriz, adquire uma feição escultórica, exceto pelo olhar, melancólico e pensativo, que ressuma a vida interior, quiçá cheia de mistérios, da bela modelo.

Já no romance $A$ margem imóvel do rio, o protagonista, um historiador, igualmente se vê na contingência de colocar em dúvida o arcabouço da sua ciência, tendo de, por fim, desacreditar a história como discurso capaz de recuperar a verdade dos fatos. Sai da cidade do Rio de Janeiro, onde ocupava o cargo de cronista da Casa Imperial e era membro do Instituto Histórico e Geográfico, em missão conferida pelo Imperador Dom Pedro II. Numa primeira viagem ao sul, da qual também o historiador teria participado como cronista oficial, o imperador supostamente condecorara com o título de Barão da Serra Grande um 
estancieiro, que agora reclamava a honraria. Deslocando-se para o sul, nesta volta sobre os próprios passos, na tentativa vã de recuperar o acontecido, nosso historiador vê suas anotações da primeira viagem revelarem-se inúteis, incapazes de devolver-lhe à memória os caminhos percorridos. Ao abrir o antigo caderno número 17, em que figuravam as notas daquela primeira viagem, dá-se conta de que elas não lhe são de grande valia. Por exemplo, a marcação da distância em relação a uma das propriedades, embora com números exatos, seis léguas, não lhe indicava a direção, se para o sul ou para o norte. Percebe, então, que a passagem do tempo, vinte e um anos, muda as coisas, as lembranças e, estranhamente, muda o próprio espaço. Este último, como numa tocata e fuga, sempre o mesmo, é sempre diferente: quer porque é categoria continuamente em movimento e em transmutação, quer porque $\mathrm{o}$ sujeito que o percorre pela segunda vez já é outro. E, mais do que isto, os pampas, ao se descortinarem à visão inquiridora do historiador, são, na verdade, objeto por ele construído, como espaço que se dá à percepção com o cruzamento de tempos diferentes do sujeito observador: o tempo presente, mas também o da memória, na recuperação de espaços e paisagens móveis.

Nesse sentido, a gênese da paisagem como produto cultural está ligada, mais do que a uma espécie de metafísica do olhar, a qual, ao sublimar a vista no pensamento, permite ver o que o olho não vê (pense-se, por exemplo, no Merleau-Ponty de $O$ visivel e o invisivel), à subjetividade histórica de um processo de interpretação da realidade, revelando-se, ao mesmo tempo, um autêntico ato de fundação (Mulinacci, 2009, p. 12).

Se a constatação da mudança elaborada pela passagem do tempo de alguma forma apazigua, naquele primeiro momento, a personagem quanto à infalibilidade de seu métier de historiador, a aporia incontornável da representação do tempo passado não escapa à sutileza do narrador: "Não sabia ele de um fato: o pampa é único e perpétuo, e a memória é múltipla e frágil" (Assis Brasil, 2003, p. 72). Contraditoriamente, até mesmo o narrador acrescenta uma outra a estas visões móveis sobre os pampas, servindo-se do substrato tradicional que confere peculiaridade à região, enfatizando sua extensão e singularidade, embora imóveis. Não é sem razão que sua definição utiliza termos como "único" e "perpétuo". Apesar disso, ao referir-se às pretensões do historiador, o narrador repete ser o espaço só apreensível 
pelo trabalho da memória, esta última sempre falha, incompleta e móvel. ${ }^{4}$ Tais articulações fazem do romance de Assis Brasil uma realização literária complexa, em que a representação da paisagem, significada pelo investimento de diferentes sujeitos, é feita com o concurso de vozes em tensão permanente. Torna-se sofisticada, com isso, a interiorização, na narrativa, de conceitos sobre a espacialidade e sua representação, uma vez que os pampas não são apenas fruto da subjetividade de personagens e narrador. É a literatura, a especial mediação promovida pela linguagem que cria a paisagem, até mais densa e múltipla do que o espaço empírico.

Se, com efeito, no entender de Michael Jakob [...] a paisagem, por paradoxal que pareça, "não é um fenômeno objetivo, medível e existente por si, mas algo que nasce em virtude da ação do homem e que depende dele", cabe, então, à arte em geral - isto é, à literatura não menos que às artes figurativas - a tarefa de transformar a visão do sujeito numa forma mundi, virando assim pelo avesso a tradicional abordagem mimética do problema da representação (Mulinacci, 2009, p. 12, grifo no original).

À medida que se desloca no presente, tentando sempre se apoderar do passado, o historiador abre mão de suas certezas. Não podendo apreender os acontecimentos como um todo sem lacunas, fracassa na sua tarefa. Contudo, tal fracasso redunda na amplificação do seu poder de alcance das nuances da realidade que o circunda e do conhecimento da própria subjetividade. Seu percurso encena uma espécie de memória performática, um "rastro atrás" sendo apagado ao mesmo tempo que apaga e esvazia a história. Já ao final da narrativa, volta ao caderno 17 e "em dois ou três movimentos da borracha sobre o papel, o Historiador apagou o nome que o martirizara. Francisco da Silva desaparecia da memória, tragado nas paragens do Sul. E a História passava a ser outra" (Assis Brasil, 2003, p. 166).

Joaquim José de Mendanha, por sua vez, o músico dotado de ouvido absoluto e protagonista do romance Música perdida, se vê às voltas com a perda da partitura que seria sua obra-prima e que, inutilmente, tenta reconstituir ao longo da vida. O roteiro do maestro inicia-se na pequena

\footnotetext{
${ }^{4}$ Vale lembrar que em $O$ pintor de retratos o narrador, num dado momento, também assume como seu o espaço do sul, presentificando por meio dele a narrativa: "Aconteceu um fato que modificou a vida de Sandro Lanari aqui em Porto Alegre [...]” (Assis Brasil, 2002, p. 76, grifo nosso).
} 
Itabira do Campo e prossegue rumo a Vila Rica, onde encontra seu primeiro mecenas. Da capital das Minas, sempre em ascensão como artista, chega ao Rio de Janeiro, sede da recém-trasladada corte de D. João VI, onde trava estreita relação com o Padre-Mestre José Maurício. No auge da carreira, porém, a angústia ao se ver traído pela memória incita uma última viagem rumo à fria Porto Alegre, local em que verá findarem seus dias. $\mathrm{Na}$ verdade, o deslocamento do personagem para o sul sinaliza a fuga de um ambiente que, a seu ver, lhe cobra continuamente a mesma genialidade antes alcançada com a "música perdida". A busca, a insistência na recuperação pela memória da cantata que, com certeza, o teria consagrado em definitivo, consomem-lhe a saúde e a capacidade de novamente criar. Ele, assim, no sentido mais doloroso do termo, perde sua música. Somente no final da vida, quando, enfim, a recupera, pode considerar-se pronto para morrer, quase bem-querendo a morte:

Ajeita-se ao comprido da cama, tentando subjugar a dor, cada vez mais intensa. Agora doem os maxilares. A mão amassa o lençol, a testa inunda-se de um suor gélido.

“Vem, e que não sejas rápida" (Assis Brasil, 2006, p. 213).

Aimé Bonpland, por fim, o quarto protagonista da série, é, ao mesmo tempo, o mais famoso dentre os personagens históricos ficcionalizados na tetralogia, mas, contraditoriamente, sobre quem mais pesa a sombra da história. É ele a figura na sombra que dá nome ao romance, imagem que metaforiza sua relação com o famoso cientista Alexander von Humboldt, mestre e mecenas. Acompanhado de maneira irregular pelas lentes da narrativa desde seu nascimento, em 1773, até sua morte, em 1858, o naturalista francês encena um périplo de viagens em que o fim e a realização são sempre adiados. Sua vida, um constante migrar. Da França para a América, a travessia do oceano, a exploração de rios, florestas e cordilheiras no alto Amazonas. No retorno à Europa, a serviço da imperatriz Josefina da França, conhece a impossibilidade do amor e torna-se incapaz de cumprir os compromissos com o amigo e companheiro de viagens, Alexander von Humboldt. Com isso, novo deslocamento, uma fuga para a América que tanto o fascinara, uma volta nos próprios passos. Desta vez, vai para Buenos Aires, mas por pouco tempo. Logo subirá o rio Paraná, em direção ao nordeste da Argentina, depois Paraguai e Rio Grande do Sul, sempre buscando no futuro algo que perdera no passado. De novo é o espaço do pampa que, 
já nas primeiras páginas do romance, condensa tempos. "Mas tudo ali é passado. No pampa, todos os cômodos de uma casa são passado. No pampa, tudo é passado" (Assis Brasil, 2012, p. 3).

Na direção oposta ao cientificismo dos séculos em que viveu, o personagem é construído, pela mão da ficção contemporânea, como um homem multifacetado, inapreensível em sua totalidade, da mesma forma como o são os outros "visitantes ao sul". Contrariamente ao projeto de Humboldt, que viaja para comprovar o equilíbrio e a harmonia do cosmos, a ligação invisível entre os integrantes dos diferentes reinos da natureza, Aimé Bonpland representa o desafinamento do mundo, uma contraface ao desejo totalizador humboldtiano.

Minha viagem com Humboldt foi errática, comandada pelas pestes, pela política, pela paixão, pela geografia, pela boa ou má disposição dos capitães de navios. O gênio de Humboldt deu sentido a uma aventura dirigida pelo acaso. A viagem, para ele, foi um meio para comprovar sua teoria. Ele buscou a totalidade em meio à confusão dos seres. Ele morrerá com a certeza de havêla encontrado. Quanto a mim, encontrei a solidão, a malária e o amor. Depois disso, encontrei o pesar o remorso e, por fim, a remissão e a sabedoria. E quanto mais vivo, mais constato que tudo é diverso, tudo é frágil, tudo é múltiplo e surpreendente (Assis Brasil, 2012, p. 8-9).

A oposição entre as figuras de Humboldt e Bonpland, ficcionalizada no romance com acento no plano subjetivo, é marcada pela historiografia.

O mundo dos "homens de ciência" estava identificado a um espaço geográfico, cultural, político e econômico preciso, onde deveria ser produzido o conhecimento científico. A América era vista só como a matéria-prima - virgem - para a produção desse conhecimento. Após a viagem de cinco anos pelo "Novo Continente" (1799-1804), Aimé Bonpland e Alexander von Humboldt empreenderam caminhos diferentes: enquanto Humboldt regressou e permaneceu na Europa escrevendo e publicando os resultados da expedição, Aimé decidiu voltar para América. Enquanto Humboldt colhia o reconhecimento de seu trabalho, a admiração e a fama no mundo inteiro pela sua "reinvenção ideológica da América do Sul", Bonpland não participava de igual sucesso nos pampas (Moreira e Quinteros, 2008 p. 223). 
De fato, conforme demonstra o estudo histórico de Moreira e Quinteros (2008, p. 233-234), Humboldt e Bonpland seguiram caminhos distintos após sua famosa expedição pela América. Enquanto o primeiro escolheu permanecer na Europa e dar sequência a seus escritos sobre o "Novo Mundo", local de natureza ainda virgem, à espera dos meios e dos capitais capazes de ali produzir riquezas, o segundo escolheu como lar o continente ainda bastante desconhecido e convulsionado por instabilidades políticas. Segundo os autores, "Bonpland participou neste universo de rivalidades, mas geralmente do lado daqueles que foram derrotados. Isso traduziu-se não só em solidão e empobrecimento material, senão também na não transcendência política de Aimé" (Moreira e Quinteros, 2008, p. 234). Isso se verifica no romance de Assis Brasil, em que a história e a literatura se aproximam apenas na medida necessária à fatura artística da obra. Com efeito, em Figura na sombra, as relações políticas de Bonpland não são privilegiadas pelo foco narrativo, o que contribui para mantê-las à margem da história. Ainda assim, através da ficcionalização dos elementos disponíveis, a obra presta especial atenção à inserção dissonante do botânico no pensamento de sua época. Enquanto Humboldt buscava a precisão e a ordenação do universo, Bonpland atraía-se pelos elementos imprevistos dentro da perfeição do cosmos, como "uma inacreditável borboleta de asas amarelas, pousada na ponta de um calhau negro que emergia da neve. Impossível essa borboleta em tal altitude" (Assis Brasil, 2012, p. 80). Desta borboleta, não falaria a Humboldt, seria um segredo seu, apenas tornado possível pela mão da ficção, que transcende a história e propõe novos significados.

Bonpland, como os protagonistas dos outros romances da série, exibe as contradições, sem possibilidade de síntese, próprias do sujeito da modernidade. Seu percurso - inúmeros deslocamentos pelo continente americano - encena a inquieta busca identitária do sujeito, de saída condenada à falência. Se o personagem é histórico, recuperado ao século XVIII, suas contradições e a consciência que delas apresenta mesclam a personagem às representações do sujeito contemporâneo semelhantemente, de resto, à incompletude dos personagens dos outros romances. A incompletude literariamente procurada pode ser sintetizada na frase de um desconhecido sobre o pintor de retratos, já no final da narrativa: "É o retrato de um homem, mas é impossível formá-lo por inteiro. Faltam muitos pedaços, muitos..." (Assis Brasil, 2002, p. 181). 
Nada é plenamente recuperável. A fotografia capta apenas um fragmento do vivido; a história não registra o que ocorreu, mas representa tão somente perspectivas dos fatos; a música existe só no instante da execução e depois se perde; a ciência não pode explicar a completude do cosmos, tampouco resumir a vida de um homem. Para esses Visitantes ao Sul, ao que tudo indica, apenas no transcorrer de uma vida inteira, no entre-lugar do trânsito e no aportar em novos espaços pode brotar alguma resposta, ainda que sempre provisória e incompleta. É preciso atravessar tempo e espaço.

As quatro narrativas, portanto, trazem à cena personalidades históricas ficcionalizadas. Se em Figura na sombra o leitor se defronta com Aimé Bonpland e Alexander von Humboldt, em $O$ pintor de retratos e A margem imóvel do rio o fotógrafo Nadar e o Imperador Dom Pedro II não têm papéis desprezíveis. Música perdida, por sua vez, faz do padre José Maurício, conhecido compositor do tempo colonial, personagem importante no desenvolvimento da trama, enquanto Joaquim José de Mendanha recupera da história o músico que gozou de certa fama na Porto Alegre do século XIX.

Mendanha é inclusive mencionado, de passagem, em pelo menos dois outros romances do autor: Concerto campestre e Cães da província. Assinala-se com isso a recorrência da música na obra de Assis Brasil, ele mesmo violoncelista, integrante que foi, por 15 anos, da Orquestra Sinfônica de Porto Alegre. Sua novela O homem amoroso, por exemplo, com claros toques autobiográficos, também tem na música a temática central. Com efeito, pode-se observar uma espécie de harmonia final a fechar as narrativas que compõem Visitantes ao Sul. É ao campo semântico musical que recorre o historiador quando, ao retornar ao Rio de Janeiro, passa a ouvir, como música harmoniosa, os sons que vêm da rua.

O Historiador parou para escutar. Algo sucedia, extraordinário e belo: muito pausadamente, como os lampiões de uma rua que um por um se apagam ao amanhecer, as suas cigarras calavam-se. Sobre o cantochão das vozes da Praça, agora ressoando em harmonia, passava a ouvir com nitidez o mar à distância, ouvia o fino ramalhar das folhas da mangueira, ouvia o vento perpassando as quinas do Chafariz. Ouvia até o pulsar do coração. [...] ele pôde, enfim e para sempre, experimentar a pureza de todos os sons do Universo (Assis Brasil, 2003, p. 166-167). 
Como historiador, agora no espaço republicano, são as vozes dos populares, dos pregoeiros e passantes que atravessam a praça aquelas que valoriza. Simbolizando uma espécie de reconversão de sua visão do mundo, ou antes, uma reconversão de sua "audição do mundo", tornase consciente da insuficiência das palavras para exprimir os sentimentos. Mais do que isso, mesmo que internamente, reconhece a linguagem musical como suporte para a impressão que lhe causa o mundo que o cerca. É como "músico", portanto, que se quer, agora, historiador. "Naquele arrebatamento feliz, tentou formar uma de suas eruditas frases mentais para descrever o que sentia, mas frases não eram mais necessárias: sua alma, a partir de agora, compunha músicas" (Assis Brasil, 2003, p. 167).

Já em Figura na sombra, a música parece atuar como uma metáfora expansiva, no sentido de que percorre toda a narrativa, desdobrando-se em novos significados.

A imagem de um piano, repetida em diferença, promove investimentos afetivos das personagens, marcando, inclusive, momentos cruciais do desenvolvimento da história. Logo no início da narrativa, quando se desenha "a cena infantil de Aimé Bonpland" (Assis Brasil, 2012, p. 10), o aprendizado do piano lhe é proposto como substitutivo do interesse pela Botânica. “A irmã, para distraí-lo desses assuntos, começou a ensinar-lhe piano. Em poucos meses tocavam a quatro mãos o movimento Andante da sonata em Dó Maior para dois pianos de Mozart" (Assis Brasil, 2012, p. 11). A estratégia, no entanto, não dá frutos, uma vez que o aprendizado quase autodidata desenvolvera tantos vícios de dedilhado que o professor logo desiste do trabalho, gerando na personagem possivelmente sua primeira culpa: "Essa foi uma culpa perante seu pai. Não podia vê-lo sem imaginar o desgosto que ele sofria" (Assis Brasil, 2012, p. 11).

Tal imagem é como um tema musical que retorna, em variações que enriquecem, adensam a linha melódica que corta as narrativas, que as estrutura. O piano, pois, ressurge em Paris, onde aos dezessete anos Bonpland estuda medicina. "No manicômio da Salpetrière, Philippe Pinel ensinava aos estudantes de medicina como entender as pacientes dos nervos, sem algemas nem castigos. Havia até um piano, ali. Aimé Bonpland tentou dois acordes. Estava desafinado" (Assis Brasil, 2012, p. 18). No local, que ao final da trama se revelará significativo, o instrumento desafinado remete não só à loucura dos pacientes, mas também à Revolução 
Francesa, que se desenrolava nas ruas da cidade, e à situação do próprio protagonista. Bonpland, então, vagava quase errante e alheio à própria sorte pelo Muséum d'Histoire Naturelle, pelo Jardin des Plantes e pela Charité, onde frequentava aulas. No Muséum, ao observar um feto de um lêmure imerso em formol num frasco de vidro, encontra nos reflexos da superfície a própria imagem: "Era uma figura humana alongada, irrisória" (Assis Brasil, 2012, p. 18). Nessa época, ainda não conhecera Humboldt, o amigo que daria o tom da sua vida e com quem dividiria experiências nada irrisórias, mas com relação a quem se sentiria em dívida por toda a vida.

Muito tempo depois, tendo já retornado das viagens pelas Américas Central e do Sul, acha-se instalado na Malmaison, residência da Imperatriz Josefina da França, e novamente num entre-lugar da sua vida. Mesmo comprometido com Humboldt no projeto de edição dos livros com os dados resultantes das pesquisas, vê-se bloqueado na tarefa pela paixão que nutre pela Imperatriz, sabendo que não poderá cumprir as promessas feitas ao amigo (Assis Brasil, 2012, p. 110) e que tampouco experimentará a consumação desse amor. Ao relatar à Imperatriz um sonho lascivo que tivera, assomam uma vez mais a imagem do piano e com ele a música que dá o compasso de momentos decisivos na vida da personagem:

Ela foi ao piano. Havia, aberta, uma partitura de Haydn. Começou a tocar. Era um movimento grave e pensativo. Eu via o seu perfil recortado contra a luz da janela. Pedi-lhe licença para sair. "Fique", ela me disse, "sente-se aqui junto a mim". Obedecia, mais uma vez. "Um sonho é como a música", ela disse, olhando para a partitura. "Um sonho, meu caro senhor Bonpland, só existe enquanto é sonhado. É como a música: só existe quando é executada. Depois, tanto o sonho como a música desaparecem. Assim também é com o amor. Um estado de sonho. De repente, é o sol do amanhecer, é a luz" (Assis Brasil, 2012, p. 127).

Naquela noite, após intensas sensações ao piano, Bonpland padece da malária adquirida no clima tropical, que o prostra por duas semanas. Quando se recupera, recebe da Imperatriz a perturbadora solicitação de casar-se com Adeline Delahaye e tornar-se um segundo pai para sua filha, Emma (Assis Brasil, 2012, p. 128-129). Logo após a morte de Josephine, desloca-se novamente. A fuga das lembranças proporcionadas pela 
Malmaison leva a recém-formada família a Buenos Aires, onde a música continuará a suscitar recordações e demarcar uma identidade perdida.

Emma, que "tocava piano bastante bem para sua idade" (Assis Brasil, 2012, p. 130), resume seus anseios em "uma delicada expectativa e um desejo maior que sua infância, um piano" (Assis Brasil, 2012, p. 145). Mais do que isso, a música guardará múltiplos sentidos quando se deslocam para o sul do continente. Emma terá sua própria Malmaison, com seu piano e um padrasto afetuoso com quem dividir, ainda que momentaneamente, a infância. Já para Adeline, o som do piano será uma constante recordação da identidade deixada para trás, perdida nos recitais do passado na França, do mesmo modo que para Aimé Bonpland, a esta altura transformado em Don Amado Bonpland.

O protagonista, muito embora tente acompanhar a enteada nos exercícios musicais, não suportará o peso das reminiscências por eles desencadeadas. Certa vez, equivocou-se na entrada do acompanhamento, e "a partir daquele dia algo mudou" (Assis Brasil, 2012, p. 151), passou a sentir uma espécie de aversão de si mesmo. Não tardou para que um dia, em meio à música, Bonpland tirasse as mãos do teclado para anunciar à menina: "Esta é a última vez que tocamos juntos" (Assis Brasil, 2012, p. 158). Tal como na "cena infantil de Aimé Bonpland" (Assis Brasil, 2012, p. 10), a música novamente não é capaz de afastá-lo da Natureza, da sua própria natureza. Pelo contrário, sendo agora capaz de evocar sensações relegadas às salas menos visitadas da memória, motiva a errância. Parte, então, rumo à selva, na busca desenfreada pela yerba que consumirá o resto dos seus dias.

Ao termo, a circularidade do motivo musical em Figura na sombra se completa como síntese de sua presença no conjunto de Visitantes ao Sul. No último capítulo da obra, Emma Delahaye vive entre a dolorosa experiência do Maestro Mendanha e a liberdade alcançada pelo historiador de A margem imóvel do rio. Esquecida no manicômio da Salpêtrière, que retorna uma última vez com seu piano desafinado, a personagem tenta encontrar num teclado, ao mesmo tempo do presente e do passado, um alento para a solidão. Entre a perda da música causada pelas mãos já quase paralisadas e a potência da imaginação, encontra dentro de si mesma o som capaz de libertá-la, ainda que a liberdade seja um refúgio na memória. $\mathrm{O}$ longo trecho tem justificado seu registro pela força imagética que confere ao final da narrativa e, de certo modo, até mesmo do conjunto de livros que compõem Visitantes ao Sul. 
Senta-se. Abre a tampa do teclado, de onde sai um perfume de madeira encerada. Abre a gasta partitura de Haydn e a coloca na estante.

Suas mãos, travadas pela artrite, cobrem-se de pintas marrons. Quando vai tocar, elas não lhe obedecem. Os dedos não alcançam a amplitude dos acordes. Mesmo que pressione as teclas até o fundo, muitas notas deixam de soar.

Mademoiselle Emma baixa a cabeça. Ela chora. Ela se torna pequena e humilde.

Acontece: a seu lado, ela vê as mãos viris e flexíveis de seu padrasto. Elas a estimulam a seguir.

Essas mãos voltam a tocar piano com ela. As mãos de Emma são de novo mãos infantis. Eles tocam. Estão na Malmaison. Estão em Buenos Aires. A musica é risonha, feliz. Tocam por meia hora.

Vêm avisar que já terminou o tempo.

A enfermeira da Salpetrière conduz Mademoiselle Emma a seu quarto, que ela compartilha com mais duas senhoras (Assis Brasil, 2012, p. 222).

Na última página do livro, mesmo depois da palavra Fim, Luiz Antonio de Assis Brasil anuncia tratar-se Figura na sombra da última narrativa da série. Um post scriptum, um suplemento que, colocado "depois do escrito", torna-se uma espécie de chave, convida à releitura, a mais uma volta na peregrinação do leitor pelos romances, um novo ressoar dos Leitmotive das narrativas. É à imagem do tema e suas variações que recorre para definir o conjunto, reiterando a presença do campo semântico musical como articulador dos significados de Visitantes ao Sul.

Este livro é o quarto e último da série Visitantes ao Sul, do qual fazem parte O pintor de retratos [2001], A margem imóvel do rio [2003] e Música perdida [2006]. Todos pela L\&PM. Comportam leitura independente. São variações sobre um tema (Assis Brasil, 2012, p. 224). ${ }^{5}$

Se o tema refere-se ao motivo, à ideia que prevalece numa composição, as variações alteram-no, transformam-no, mantendo-o, todavia, na "memória": sempre o mesmo, embora outro (Cf. Marques, 1987). Como memórias em contraponto, os protagonistas de Visitantes ao

\footnotetext{
${ }^{5}$ Lembre-se de que também ao final de Música perdida, nas notas do autor, pode-se ler: "Este livro forma, com $O$ pintor de retratos e $A$ margem imóvel do rio, um conjunto a que posso chamar de Visitantes ao Sul. São variações sobre um tema - e variações podem ser infinitas" (Assis Brasil, 2006, p. 222).
} 
Sul são linhas do mesmo canto, vozes em fuga, alternância/permanência, cada vida e cada obra encerrando em si um oculto rosto.

Desde a origem, a palavra fuga guarda os sentidos advindos de uma dupla etimologia: fugere (fugir) ou fugare (caçar). Uma voz foge da outra ou vai à caça da outra (Cf. Krehl, 1930). Sua imagem musical, semelhante ao movimento da espiral, é a do se expor e fugir, do correr atrás de si mesmo, querendo e não querendo se encontrar, porque o encontrar-se pode significar o fim, a morte. Na estrutura da fuga não há grupos de temas distintos, mas um tema executado por diferentes variações decorrentes da voz que se está apresentando. Em alternância, a apresentação é sempre algo diferente a cada vez. O tema, anunciado logo no início, desaparece, reaparece, flui e foge com diferentes sonoridades, embora seja permanente no decorrer de um processo musical. Mas, se a palavra processo indica um desenrolar no tempo, no caso da fuga não se trata de uma evolução linear, mas de um desabrochar dinâmico, um desvelar das potencialidades dos elementos presentes no tema, uma contemplação a partir de perspectivas que nele já se encontravam, configurando um sistema que busca autointerpretar-se.

Veja-se que o recurso ao tema e suas variações percorre efetivamente vários momentos das quatro narrativas. Já no início de Música perdida, compara-se o balbucio triste de uma criança a uma cantiga infantil com vinte e duas notas, que comporta diversas variações:

Era belo. Disse: "Agora a primeira variação". Acionando o segundo teclado com a mão esquerda, a mesma frase voltou, ainda delicada, fazendo um contraste com a anterior; era a mesma frase sim, mas era outra, adensada e colorida, que conversava com a primeira. Disse: "Segunda variação". A frase tornou-se "Terceira variação". A melodia ganhava uma complexidade sonhadora, diluindo-se em arpejos, evocando bosques e caçadas. "Quarta". Ninguém mais reconheceria a canção do tema: um compasso estranho transformara-o numa escala que ondulava como panos ao vento. A frase iniciada pela mão esquerda era completada pela mão direita (Assis Brasil, 2006, p. 33).

Não suficiente, muitas das falas e pensamentos do Padre-Mestre José Maurício, com um sentido de síntese reflexiva sobre a vida, também lançam mão da imagem musical: a miríade de variações dos seres humanos diante da vida, tema proposto por Deus. 
A vida nunca é a mesma. Ou melhor, é sempre a mesma, mas comporta mil feições. A vida é um tema que nos é dado por Nosso Senhor Jesus Cristo. Cada qual, segundo suas habilidades, encarrega-se de elaborar as variações. Por isso é que há os insensíveis e os artistas, os debochados e os virtuosos, os dóceis e os irascíveis (Assis Brasil, 2006, p. 64).

Do mesmo modo, o constante deslocamento do historiador de A margem imóvel do rio e a migração de Aimé Bonpland e de Sandro Lanari representam de maneira mais ou menos explícita um andamento similar à evolução temática da fuga. Fugir e perseguir invariavelmente se imbricam na história dos personagens e contribuem para o tom de errância que imprime às narrativas sua feição contemporânea. Atormentados por um passado do qual desejam de alguma maneira se livrar, os três homens, cada um a seu modo, fogem de um elemento que sempre retorna e impõe novos significados aos acontecimentos do presente por eles vivido. Nesse movimento de espiral, em que o desejo de encontrar a si mesmo é intermitente, como na fuga musical em que o encontro pode significar a morte, os personagens de Visitantes ao Sul, migrantes que são, se movem nos limites entre as lembranças e os desejos.

O historiador, duplamente perseguido pelo passado, entrevisto nas figuras da falecida Cecília e do estancieiro Francisco da Silva, foge errante pelo interior do Rio Grande de Sul, desviando-se dos caminhos e delongando-se em divagações, ao mesmo tempo que se defronta com a necessidade de encontrar sentidos para o fantasma que o persegue e a solução para a ordem do Imperador. Sandro Lanari, emigrado da Europa, jamais se livra da imagem pretérita de Nadar, que volta a todo momento para ressignificar suas experiências. Numa dança fluida, fugidia, as fotografias do passado retornam e se confrontam com aquelas do presente, impondo o movimento, a busca, até o encontro final e definitivo com o famoso fotógrafo. Já Aimé Bonpland, acompanhado pelo som do piano que anuncia um tema que retorna, desloca-se pelo continente americano, sendo sempre alcançado pelo amor do passado e pelo compromisso não cumprido, sempre pairando sobre ele a sombra da qual busca se livrar, riscando o mapa do continente. O próprio relato de sua vida a Avé-Lallemant metaforiza a imagem de uma linha melódica que retorna a um só tempo igual e diferente, como na fuga musical, na consciência que tem o protagonista do significado de recompor pela memória duas vezes a mesma história 
de vida: "Quando lhe contei os fatos da minha vida pela primeira vez, foi pensando no que o senhor diria para o mundo e para minha Posteridade; na segunda vez, eu contei tudo debaixo do sentimento da vergonha e do perdão. Eu precisava ser perdoado" (Assis Brasil, 2012, p. 213).

Fugindo do passado, reencontrando-o em alguma entrelinha da memória, expondo-se e escondendo-se, os protagonistas do romance tecem as inúmeras variações que compõem, como se com um fundo musical, a complexa e delicada fatura final dessa tetralogia.

Mas também, como já se viu, há nas dimensões espacial e temporal, duas faces importantes para a reflexão sobre o quarteto de romances. Ligada aos mecanismos de recuperação da memória, a dimensão temporal promove nas quatro narrativas o inventário de acontecimentos que constituem a vida dos sujeitos, na recuperação que fazem das memórias individual e coletiva. Inseridos na temporalidade própria ao chamado fin de siècle, seus percursos mimetizam, de diferentes maneiras, a memória histórica, travando diálogos em que se personificam o local e o nacional, partes do amplo processo modernizador ocidental.

Em $O$ pintor de retratos, por exemplo, colocam-se lado a lado vivências diferenciadas do mesmo tempo histórico, como a chamar a atenção para variações da modernidade em espaços tão diferentes como o Brasil, mais especificamente a região Sul, sacudida por revoltas, e Paris, palco de revoluções artísticas.

No Rio Grande do Sul as revoluções ocorriam sem que as causas ficassem claras. [...] Na infância da República aconteceu um dos mais selvagens conflitos da História. [...] Por vezes eram degolados cinquenta em um só dia. Os coronéis esqueciam-se de comunicar esses morticínios a seus superiores. E os superiores dedicavam-se à política.

Em Paris, Rodin esculpia Le baiser em mármore finíssimo, e Debussy compunha l'Après midi d'un faune.

Nadar consolidava-se como o maior fotógrafo do século, ao retratar Debussy e Rodin (Assis Brasil, 2002, p. 120-121).

Cruzam-se, pois, problemáticas e temporalidades diversas na constituição dos espaços narrativos, em que estranhamente é a representação do presente o objeto de disputa.

Em seu texto Sobre a modernidade: o pintor da vida moderna, Baudelaire nos fala de novos paradigmas a constituir a Modernidade. Tomando como exemplo o pintor Constantin Guys, identifica o que 
seria o perfil da arte moderna: uma arte mnemônica, não mais visando à reprodução do real, mas que, paradoxalmente, comporta a dupla face da eternidade e do efêmero, que não se desvincula mais dos movimentos da moda, da mobilidade própria aos novos tempos.

O belo é constituído por um elemento eterno, invariável, cuja quantidade é excessivamente difícil determinar, e de um elemento relativo, circunstancial, que será, se quisermos, sucessiva ou combinadamente, a época, a moda, a moral, a paixão. Sem esse segundo elemento, que é como o invólucro aprazível, palpitante, aperitivo do divino manjar, o primeiro elemento seria indigerível, inapreciável, não adaptado e não apropriado à natureza humana (Baudelaire, 2002, p. 10).

Para Baudelaire, Constantin Guys simbolizaria o pintor da vida moderna, uma vez que não carrega mais suas telas para junto da paisagem que quer "reproduzir". Antes, percorre o espaço urbano, recorta-o fragmentariamente com seu olhar aguçado e, só à noite, numa luta com as ideias e imagens, como nos diz Baudelaire, passa para a tela o que recolheu, o que reservou na memória com uma qualidade nova do olhar (Baudelaire, 2002, p. 23-34). Atento à moda, incorpora também à sua arte o efêmero, o transitório. Mobilidade e trânsito, pois, já se encontram presentes no projeto moderno, mas se apresentam como realidades intensificadas e ressignificadas pelos processos de globalização da assim chamada pós-modernidade. A narrativa contemporânea, na construção de significados no espaço da cultura, justapõe diversos textos e variados elementos textuais, desestabilizando os lugares de enunciação. Agregando intertextos literários e históricos, acena com a possibilidade de reescrita das histórias que formam a história.

A geógrafa inglesa Doreen Massey conceitua o espaço como uma realidade em trânsito, uma variedade heterogênea de práticas, um processo sempre inacabado de interconexões. Segundo ela, o espaço é constituído por uma multiplicidade de trajetórias, de ligações contraditórias e inesperadas entre narrativas. Chegar a um novo lugar significa tornar-se associado às histórias de que este lugar é feito (Massey, 2009, p. 176). Local e global, pois, nessa perspectiva, se constituiriam em contínuo diálogo como textos que remetem um ao outro mutuamente, interrelacionando-se. Tais considerações sobre o espaço no seu imbricamento com o tempo dos diferentes relatos iluminam a prática discursiva de Assis Brasil. Suas personagens, em 
constante deslocamento, não o fazem somente enquanto viajantes. Promovem também complexas viagens interiores, associando, em função da mobilidade, suas vivências, suas "narrativas" àquelas em trânsito no espaço para o qual se deslocam. No percurso de "intramoção" (Hanciau, 2009), de deslocamento para o interior da subjetividade dos protagonistas, reconstituem-se, nos três primeiros romances, o contexto brasileiro de finais do século XIX, também ele móvel em função das interpretações variadas a que está sujeito, e ainda a conjuntura intelectual europeia na virada do século XVIII para o XIX no caso de Figura na sombra. No bojo da modernização observada no Ocidente, sobretudo pela ciência naturalista de Bonpland e Humboldt no quarto livro, percebe-se pelas outras obras que também no Brasil configura-se um imaginário de modernidade, embora tardia. Assim, acompanhando a trajetória do pintor, do historiador, do músico e do cientista, modificam-se as paisagens físicas e humanas, transformam-se os tempos e com eles os costumes. Nossos visitantes, por seu turno, também se modificam na tensão dialógica propiciada pelos percursos.

Ainda que os enredos dos romances sejam situados num período específico da história e fique evidente para o leitor todo um substrato de pesquisa prévia feita pelo escritor, não se ocupam as narrativas de grandes personagens históricos. Ao discorrer sobre A margem imóvel do rio, Flávio Carneiro salienta aspectos igualmente válidos para os outros três romances: o foco narrativo privilegia o personagem obscuro, em detrimento do grandioso, "desviando o leitor da glamourosa capital do império para a região inóspita, desconhecida quase, da então chamada Província de São Pedro do Rio Grande do Sul" (Carneiro, 2005, p. 242).

Desse modo, Assis Brasil insere-se na importante linha da literatura brasileira contemporânea que reflete sobre o passado, relendo-o a partir da margem, isto é, dando novo sopro de vida ao gênero romance histórico. Como já se disse, é através das memórias individuais que transitam o contexto histórico coletivo e mesmo os fatos oficialmente marcados pela historiografia. Nesse sentido, é possível dizer que, a partir de personagens triviais, o autor tece uma prosa "realista", seguindo tendência marcante na produção artística contemporânea, mas com uma dicção peculiaríssima, elegante e sóbria.

Em outras palavras, o romance histórico de Assis Brasil responde, entre outras coisas, a um imaginário contemporâneo da mobilidade. A insistência na Região Sul, constância, de resto, perceptível em toda a obra do autor, 
alinha-o ainda à propensão da produção atual de muitas vezes se debruçar sobre o espaço regional com um interesse marcadamente culturalista. Foge, assim, tanto da temática estreitamente nacionalista quanto dos estereótipos largamente convencionados como sendo característicos das culturas regionais. Com isso, em textos como os do autor, a região não surge como espaço a ser observado, mas como um complexo local de trânsito, de trocas e como ponto propício para observar, nas entrelinhas da subjetividade das personagens, um espectro mais amplo de acontecimentos.

A partir do espaço periférico, essa ficção olha para as grandes questões próprias à sua contemporaneidade.

\section{Referências}

ASSIS BRASIL, Luiz Antonio de (2002). O pintor de retratos. 6. ed. Porto Alegre: L\&PM.

ASSIS BRASIL, Luiz Antonio de (2003). A margem imóvel do rio. Porto Alegre: L\&PM.

ASSIS BRASIL, Luiz Antonio de (2012). Figura na sombra. Porto Alegre: L\&PM.

ASSIS BRASIL, Luiz Antonio de (2006). Música perdida. Porto Alegre: L\&PM.

BAUDELAIRE, Charles (2002). Sobre a modernidade: o pintor da vida moderna. 3 . ed. Rio de Janeiro: Paz e Terra.

CARNEIRO, Flávio (2005). No país do presente: ficção brasileira no início do século XXI. Rio de Janeiro: Rocco.

HANCIAU, Núbia (2009). Escrituras e migrações. In: WALTY, Ivete Lara Camargos; CURY, Maria Zilda Ferreira; ALMEIDA, Sandra Regina Goulart (Org.). Mobilidades culturais: agentes e processos. Belo Horizonte: Veredas \& Cenários, p. 265-283.

KREHL, Stephan (1930). Fuga. Buenos Aires: Labor.

MARQUES, Henrique de Oliveira (1987). Dicionário de termos musicais. Lisboa: Estampa.

MASINA, Léa (1995). O códice e o cinzel. In: MASINA, Léa. Luiz Antonio de Assis Brasil. 2. ed. Porto Alegre: Instituto Estadual do Livro; ULBRA; AGE.

MASSEY, Doreen (2009). Pelo espaço: uma nova política da espacialidade. Tradução de Hilda Pareto Maciel e Rogério Haesbaert. Rio de Janeiro: Bertrand Brasil. 
MOREIRA, Luiz Felipe Viel; QUINTEROS, Marcela Cristina (2008). Em busca de Aimé Bonpland. Fronteiras, Dourados, v. 10, n. 18, p. 221-236.

MULINACCI, Roberto (2009). Um deserto cheio de lugares: topografias literárias do sertão. In: RAVETTI, Graciela; CURY, Maria Zilda; ÁVILA, Myriam (Org.). Topografias da cultura: representação, espaço e memória. Belo Horizonte: Editora UFMG, p. 11-31.

WEINHARDT, Marilene (2006). O romance histórico na ficção brasileira recente. In: CORREA, Regina (Org.). Nem fruta, nem flor. Londrina: Humanidades.

Recebido em janeiro de 2014.

Aprovado em julho de 2014.

\section{resumo/abstract}

\section{Narrativas ao Sul: deslocamento e música em romances de Assis Brasil}

André Tessaro Pelinser

Maria Zilda Ferreira Cury

Visitantes ao Sul é o título do conjunto de romances publicados por Luiz Antonio de Assis Brasil entre 2001 e 2012. Neles, o escritor retoma o tema da viagem na literatura, pondo em cena personagens em constante deslocamento. Neste ensaio, analisa-se não só o trânsito por que passam os quatro protagonistas, em seus contatos com diferentes espaços culturais, como também a sua inserção na temporalidade específica da modernidade e do chamado fin de siècle. Característica do conjunto de romances, investiga-se também a temática musical que não raras vezes empresta cadência à mobilidade das personagens, desdobrando-se em metáfora expansiva e propondo novos significados às narrativas.

Palavras-chave: espaço, mobilidade, música, romance histórico, Visitantes ao Sul, Luiz Antonio de Assis Brasil.

\section{Narratives towards the South: travel and music in four novels by Assis Brasil}

André Tessaro Pelinser

Maria Zilda Ferreira Cury 
Visitantes ao Sul is the title of a set of novels written by Luis Antonio de Assis Brasil and published from 2001 to 2012. In such novels, the writer deals with traveling as a literary theme, presenting characters in constant movement and, sometimes, in situations of displacement. This paper aims at analysing not only the transit experienced by the four protagonists of the novels, taking into account their contacts with diverse cultural spaces, but also intends to reflect upon their insertion in the specific temporality of modernity and in the so-called fin de siècle. This paper also discusses one feature that characterises that set of novels: music, which frequently provides the characters' mobility with a rhythm, implying the development of a comprehensive metaphor and suggesting new meanings to those narratives.

Keywords: space, mobility, music, historical novel, Visitantes ao Sul, Luiz Antonio de Assis Brasil. 